\title{
Magistra magistrorum: Hildegard of Bingen as a Polemicist against False Teaching
}

\author{
Andra Alexiu*
}

The present paper explores the role that gendered concepts of teaching, preaching, and prophecy played in the polemical writings of Hildegard of Bingen. As this type of discourse was an integral part of the prophetic persona, the analysis focuses on how it shaped itself in order to remain within the boundaries of orthodoxy, which forbade women to preach. Employing a prophetic persona was one of the few means through which women were able to produce texts that could tackle problems which affected the Church in its entirety, such as heresy. The concept of teaching, more precisely the sharp distinction between good and false teaching are essential for understanding not only how Hildegard viewed her mission, but also how this mission was supposed to be carried out within the limits accepted by the Latin Church. By inspecting the manner in which bad and false teaching were thematised in order to serve as a polemical instrument, one can glean how polemics were embedded in texts. A careful analysis of the source material thus needs to start from a theoretical discussion of sermon and preaching - as the texts analyzed here have traditionally been linked with both of these concepts. Scholars usually tend to overlook the ultimately performative function of preaching, yet this is what made the concept relevant in a social context.

Keywords: prophecy; teaching; preaching; audiences; public communication; heresy; gender

In an extensive letter dated 1165, John of Salisbury (1120-1180) informs the exiled Archbishop of Canterbury, Thomas Becket (1118-1170), in passing, about the activity of some unnamed German prophetesses (prophetissas Teutonicas), presumably Hildegard of Bingen (1098-1179) and Elisabeth of Schönau (1129-1164). Predictably, a fervent supporter of Pope Alexander III such as John would not have depicted the allies of the schismatic Frederic Barbarossa in the most favourable light, and the nameless sibyls are held responsible for sending the dissenting Teutons into a frenzy through the power of their prophecies. ${ }^{1}$ Only one year later, in a letter addressed to Master Gerard Pucelle (c. 1117-1184), the same John

\footnotetext{
* Correspondence details: Andra Alexiu, Historical Seminar, University of Münster (WWU), Domplatz 6, 48143 Münster, Germany. Email: andra.alexiu@uni-muenster.de.

1 John of Salisbury, Letter 152, ed. Millor and Brooke, 54-55.
} 
speaks highly of Hildegard, referring in lavish terms to the visions and the prophesies of most famous and blessed Hildegard « who, according to him, was cherished by Pope Eugenius swith an intimate bond of affection. $\iota^{2}$ While there is little contextual evidence to explain this apparently sudden shift of tone ${ }^{3}$ and attitude, both letters seem to agree that she acted as a prophetess.

A more powerful portrayal of this role is found in a letter, dated around 1170 when the visionary nun fell ill with a sickness. Lamenting the apparent imminence of her death, ${ }^{4}$ her secretary and close collaborator Volmar (d. 1173) wrote:

Who then will give answers to all who seek to understand their condition? Who will provide fresh interpretations of the Scriptures? Who then will utter songs never heard before and give voice to that unheard language? Who will deliver new and unheard-of sermons on feast days? Who then will give revelations about the spirits of the departed? Who will offer revelations of things past, present, and future? Who will expound the nature of creation in all its diversity? ${ }^{5}$

This short passage illustrates how her prophetic inspiration was perceived as a source of scriptural interpretation, sermons, and answers to those who sought to better understand their social or existential condition. It is therefore no surprise that, despite the diversity of her work, Hildegard's oeuvre finds its unifying thread in the prophetic mission that is not only claimed, but also attributed to her. In order to gain a clearer perception of what this mission entails, a passage from French theologian Alan of Lille's (c.1128-c.1202) Summa de arte praedicatoria is revelatory: 'For preaching is that type of instruction which is offered to many, in public, and for their edification; teaching is however given to one or to many to aid to their knowledge; prophecy is the admonition which is given for the revelations of those yet to come. $\kappa^{6}$ As such, for thinkers of the late twelfth century, prophecy represented a

2 John of Salisbury, Letter 185, ed. Millor and Brooke, 224-225: si non aliud occurit quod nostratibus desit, saltem uisiones et oracula beatae illius et celeberrimae Hildegardis apud uos sunt; quae michi ex eo commendata est et uenerabilis, quod eam dominus Eugenius speciali caritatis affectu familiarius amplectebatur. Explorate etiam diligentius et rescribite an ei sit de fine huius scismatis aliquid reuelatum.

3 On John of Salisbury's generally ambivalent attitude, see Grellard and Lachaud, Companion to John of Salisbury, 8-12.

4 In the end, Hildegard not only recovered, but also outlived Volmar by six years. On her collaboration with Volmar, see Mews, Male-Female Spiritual Partnership.

5 Hildegard of Bingen, Epistula 195, ed. van Acker, 443-444: Vbi tunc responsum de uniuersis casibus suis querentium? Vbi tunc noua interpretatio Scripturarum? Vbi tunc uox inaudite melodie et uox inaudite lingue? Vbi tunc noui et inauditi sermones in festis sanctorum? Vbi tunc ostensio de animabus defunctorum? Vbi tunc manifestatio preteritorum, presentium et futurorum? Vbi tunc expositio naturarum diuersarum creaturarum, diuina dante gratia cum suauissimis et cum humillimis moribus, et cum materna affectione circa omnes affluentibus uisceribus quam in te nouimus?

6 Alan of Lille, Summa de arte praedicatoria in PL 210, 112A: Ea enim differentia est inter praedicationem, et doctrinam, et prophetiam, et concionationem, Praedicatio enim est illa instructio quae pluribus fit, et in manifesto, et ad morum instructionem; doctrina vero est quae vel uni, vel pluribus fit, ad scientiae eruditionem; prophetia, est admonitio quae fit per revelationem futurorum; concionatio est civilis admonitio, quae fit ad reipublicae confirmationem. 
special form of imparting Christian doctrine, one that was quite distinct from preaching. The main goal of this article is to offer preliminary observations on how Hildegard, building on the contemporary understanding of prophecy as a distinct category of teaching, was able to articulate a polemical discourse which would then function in the public space. ${ }^{7}$

Starting from this distinction, it is quite interesting to rediscuss Hildegard's commitment to the fight against heresy, which had, in theory, provided women with an opportunity to engage in public debates. Therefore, by focusing on Hildegard's anti-heretical writings, an important aspect - which has not captured the attention of scholars so far - should be discussed, namely the role played by the concept of teaching, with its implicit gender undertones, in the construction and use of a polemical discourse.

Hildegard's involvement in the quest against the Cathars is not a new theme in itself. ${ }^{8}$ Recently, Beverly Mayne Kienzle tried to demonstrate that Hildegard's dedication to the anti-heretical activity is actually much stronger and broader than previous research used to interpret, permeating especially her Homilies on the Gospel..$^{9}$ On the other hand, many historians, such as Uwe Brunn, have brought under scrutiny the concept of Catharism, arguing that Hildegard's so-called anti-Cathar texts ${ }^{10}$ need to be seen as a product of the struggle between various clerical camps which opposed each other during the schism caused by Frederic Barabarossa's refusal to recognize the validity of Alexander III's election. ${ }^{11}$ Whether one chooses to accept Brunn's hypothesis or not, schism and heresy did share a lot in common on a discursive level and, as the texts cited at the beginning of the article illustrate, tackling them constituted one of the main parts of Hildegard's writings. Against this backdrop, one would legitimately ponder how a woman was able to produce such an influential polemical discourse ${ }^{12}$ one that was directly intertwined with all the major issues of the moment. From the fragment of Volmar's letter cited above, one can already grasp that Hildegard was, first and foremost, a dispenser of what he considered to be the good knowledge. Hence, it is quite interesting to see how the visionary nun set a clear boundary between good and bad teaching when she wrote her most powerful sermons, the ones addressed to the clergymen in Cologne, Mainz, and Trier.

7 In recent years, with an eye towards sociological theories, medievalists have been interested in refining the understanding of the concept of public, see, for example, Melve, Inventing the Public Sphere or Connnell, Popular opinion. For the limits of using Habermas's theory for the Middle Ages, see the Introduction to this volume by Sita Steckel.

8 Amongst the first publications interested in this topic, see Müller, Hl. Hildegard im Kampf; Manselli, Amicizia spirituale.

9 Kienzle, Hildegard of Bingen and Her Gospel Homilies, 245-288.

10 Apart from Brunn's book, there are other authors who seem to adhere not only to the idea that Catharism did not exist as a unitary religious phenomenon, but also that the very existence of the Cathars is questionable. On this topic, see Biller, Goodbye to Catharism.

11 Brunn, Des contestataires aux « Cathares », 247-262.

12 See especially the influence of Hildegard's sermon, included in her Epistolarium, addressed to the Cologne clergy mirrored in its history of its reception, Embach, Schriften Hildegards von Bingen, 222-228. 
One of the first obstacles this endeavour faces is to assign these polemical texts to a specific genre. Most scholars labelled them sermons ${ }^{13}$ and, furthermore, linked them to a rather exceptional preaching activity. However, as the correlation between written message and the messenger's social agency has not been thoroughly explored so far, it is rather unclear to what extent the category of "preaching " might still be accurate in Hildegard's case. As such, the rhetorical tools used in order to produce the discourse depended not only on gender, but also on the social dimension and its respective performance.

These rather abstract concepts are entangled to a degree which becomes obvious if Hildegard's case is discussed with Alan of Lille's definition in mind. For him, as well as for other monastic writers such as Rupert of Deutz, ${ }^{14}$ this activity was linked with the service at the altar and had a public dimension. Thus, using the twelfth century perception of preaching and admonishing ${ }^{15}$ proves more than useful in developing an understanding of how polemics $^{16}$ might have functioned from a gendered perspective within the orthodox frameworks established at that time. As Hildegard's writings seem to stand on the threshold between strictly defined categories, Alan's all-encompassing concept of teaching allows us to see how Hildegard viewed her mission within the Church: she was a prophetess and her role was to strongly denounce what constituted bad or false teaching, in other words deviance from Christian doctrine. As will be shown, this lay at the core of her admonitio.

In order to better understand how admonition could constitute the ground for a polemical message, one must first scrutinize the differences between categories such as admonition and predication in the words and narratives used when referring to Hildegard's activity as a prophetess or as a magistra magistrorum. This discussion will first be approached from a theoretical perspective, by looking at the main difficulties that scholars seem to be faced with when talking about sermons and preaching, and about their relation to the public debate, both in terms of audience and of (symbolic or concrete) venue. Afterwards, the study will proceed towards a closer inspection of how Hildegard viewed her mission in this context, by focusing on some of the passages in which she discusses the concept of teaching. This will not only shed light on how she perceived the range of her mission, but also on the way she positioned herself accordingly in the heated religious debates of her time by producing a polemical discourse. This, in turn, will help analyze how notions such as bad and false teaching are thematised in order to serve as a polemical tool.

13 A genre that itself raises some theoretical difficulties: Kienzle, Sermon, 143-174.

14 Van Engen, Rupert of Deutz, 317-334: In this regard Rupert adopts an apologetic position arguing for the superiority of the monk-priest and for his entitlement to the tithes with respect to his pastoral duties.

15 The practice of admonition has been the subject of several recent contributions which focused mostly on the Early Middle Ages. Suchan, Mahnen und Regieren; de Jong, Admonitio and Criticism of the Ruler. For the role that admonition played in education, see Steckel, Kulturen des Lehrens, 171-181.

16 Hettema and van der Kooij, Religious Polemics in Context; Iogna-Prat, Order and Exclusion, 120-147; Suerbaum et al., Polemic, 1-14. 


\section{Preaching in the Twelfth Century}

Given the fluidity of the genre, stressed time and again by scholars of sermon studies, defining and analysing the medieval sermon proves to be quite a difficult task.${ }^{17}$ This means that adding new perspectives to the study of preaching contributes to an ongoing refinement of our understanding of what preaching meant for different periods and different religious cultures of the Middle Ages. Compared to the rather rigid perspective on this particular genre provided by Longère, who understood preaching as a public act addressed to society as a whole ${ }^{18}$ for Beverly Mayne Kienzle the idea of audience (and not society) plays a much more significant role, providing an operational definition for the concept in question. ${ }^{19}$ While audiences are, for a modern reader, necessarily linked to what one might call going out publicly, and thus opened to a public debate, medieval thinkers tended to invest certain venues and performances with a public dimension which could restrict certain individuals from the public space either physically - based on gender as well as social criteria - or intellectually - based on the orthodoxy of the expressed ideas - or both.

In Hildegard's times, just like today in many Christian denominations, women's exclusion from the service at the altar - comprised of administering the sacraments as well as edifying the lay audience - was firmly grounded in Paul's epistle 1 Cor. 14: 34-35. Furthermore, the church was perceived (and still is) as the public space par excellence by all its members and efforts were made in order to clearly define the rules which governed this space concerning both the ritual as well as the way in which space imposed a segregation based on the abovementioned criteria.

Thus, in an "orthodox « framework, women could symbolically enter the space of the altar only by donating their handwork. ${ }^{20}$ When he proposed his classification of different forms of teaching, Alan of Lille most certainly had in mind the space of the Church and the sacerdotal office, as he referred to the public edification of the many. Another institutional venue which acted in a similar fashion was the judicial court, where women seem to have been excluded physically both in theory as well as in practice. ${ }^{21}$ Furthermore, a notable example is offered in the Chronicle of William of Puylaurens: in the eighth chapter, William describes a public debate between Dominicans and Waldensians which took place, sometime in the first decade of the thirteenth century, in Pamiers and from which the sister of Bernard-Roger, Count of Foix, was swiftly dismissed with the following words: "Go lady, and work at your distaff! It can be no business of yours to join in a debate such as this. $\aleph^{22}$ Therefore, speaking about "audience» and "performance» brings a significant addition to our understanding of what preaching

17 Muessig, What is Medieval Monastic Preaching; Kienzle, Sermon, 147-155.

18 Longère, Prédication médiévale, 12: «Prêcher c'est faire un discours public fondé sur une Révélation divine, dans le cadre d'une société organisée, visant à la naissance ou au développement de la foi et des connaissances religieuses et, corrélativement, à la conversion ou au progrès spirituel des auditeurs. »

19 Kienzle, Sermon, 151: "The sermon is essentially an oral discourse, spoken in the voice of a preacher, who addresses an audience, to instruct and exhort them, on a topic concerned with faith and morals and based on a sacred text."

20 Griffiths, Medieval Religious Women. For further references on the link between orthodoxy and preaching see the above-mentioned example of Waldensian women preachers, respectively.

21 Davies and Fouracre, Settlement of Disputes, 217

22 William of Puylaurens, Chronicle, 24. 
meant in the Middle Ages - especially if we look at those women who produced written or oral discourses which have recently been associated with public preaching. An inspection of Hildegard of Bingen's writings can provide the necessary ground for understanding the relationship between specific literary genres and their concrete agency in medieval society. Furthermore, it can also shed light on how polemics functioned when produced by women.

One of the questions that attracted the attention of sermonists over the course of time concerns the problem of authorization and its importance when drawing the borders of orthodoxy. ${ }^{23}$ The theme of women's activity as preachers is closely connected to the question of authorization and the nature of the space in which preaching was being conducted. Indeed, Hildegard has been acknowledged for a long time as one of the most outstanding women of the Middle Ages, ${ }^{24}$ precisely because she was well-known and sought out for her writings and spoken performances. But did Hildegard perceive her mission in a similar manner to that of a preacher? Being not only a magistra of a nun's convent but also the founder of two monasteries, she enjoyed greater liberty than regular nuns, especially when compared to those that were organized according to the ideal of the Hirsau reform. ${ }^{25}$ As the community from $\mathrm{Ru}-$ pertsberg was directly dependent on the abbatial authority of Disibodenberg, Hildegard needed to travel frequently in order to establish a network of friends and protectors who could secure the autonomy of her foundations. ${ }^{26}$ Both her Epistolarium and the hagiography written by Theodoric of Echternach ${ }^{27}$ state that she travelled extensively ${ }^{28}$ during her lifetime for different reasons - the most prominent regarding the dissemination of a new understanding of God's message.$^{29}$ It has, however, become obvious that one needs to take precautions when linking Hildegardian texts with public preaching. After Franz Felten briefly expressed his scepticism towards the notion that Hildegard's journeys to various monasteries and chapter houses constituted preaching tours, ${ }^{30}$ Beverly Kienzle recently conceded that:

There are no grounds for concluding that Hildegard engaged in the sort of public tours that Bernard of Clairvaux and other male ecclesiastical leaders undertook. [...] Hildegard could have spoken in the venue of a chapter house, whether a cathedral chapter, as in Cologne, where her friend Philip of Heisenberg was the Dean before becoming archbishop [sic], or the accustomed venue of a monastic chapter, where informal preaching took place on a daily basis. ${ }^{31}$

23 Kienzle, Preaching as Touchstone.

24 On the still somewhat limited bibliography on this subject, see Kienzle, Sermon, 153, 288-289; Mooney, Authority and Inspiration.

25 For a description of the female communities influenced by the Hirsau reform, see Küsters, Formen und Modelle; Hotchin, Female Religious Life.

26 For Hildegard's connection to three of the most important Dioceses in the Holy Roman Empire, see Holbach, Hildegard von Bingen und die kirchlichen Metropolen.

27 Theodoric of Echternach, Vita Sanctae Hildegardis, ed. Klaes, 54-55; Hildegard of Bingen, Epistulae 77-77R, ed. van Acker, 166-175 (esp. 174); ibid, Epistulae 149-149R, 332-337; ibid, Epistula 138, 311-312; ibid, Epistula 159, 355.

28 Kienzle, Hildegard of Bingen and Her Gospel Homilies, 51-52.

29 Theodoric of Echternach, Vita Sanctae Hildegardis, ed. Klaes, 165-175.

30 Felten, Hildegard von Bingen.

31 Kienzle, Hildegard of Bingen and Public Voices, 319. Cf. this conclusion with her earlier postulation on this topic, Kienzle, Defending the Lord's Vineyard; Kienzle, Crisis and Charismatic Authority, where she argues for a more active role for Hildegard as a public preacher. 
If we are to look at the changes that took place in the second half of the twelfth century, the fact that Hildegard could act against the reform movement taking place at the time is quite significant. For nuns, this movement brought, in theory at least, increasingly less room for manoeuvre. The second Lateran Council (1139) not only introduced the idea of a clear separation between the monastic communities of men and of women, which generally translated into a strict enclosure for women, ${ }^{32}$ but also brought the exclusion of monastic actors from preaching. ${ }^{33}$ While this ideal may have never been put entirely into practice, women seem to have been engaged - at least according to the continuously expanding body of literature on polemics - in various types of public activities that their contemporaries perceived as preaching. As such, in addition to the restrictions imposed by canon law, the end of the twelfth century saw women preachers being targeted by anti-heretical writings; the Waldensian women preachers, for instance, were described as deceitful, and therefore compared to Queen Jezebel. ${ }^{34}$ It is noteworthy that Bernard of Fontcaude (d. c. 1192), who dedicated a whole chapter of his Adversus Waldensium sectam liber to discussing the problem of women preachers, seems to have made a decisive difference between preaching and prophesying, considering the latter appropriate even for women..$^{35}$ Thus the complex religious turmoil urged many writers to operate a clear cut differentiation between categories describing the activity of disseminating the orthodox teaching. This sort of differentiation was never categorically enforced; rather, as its later transfer towards the scholastic disputes reveals, the ambiguous use of these categories created some paradoxes within the official position of the Church, of which various scholastics seemed to be nervously aware. ${ }^{36}$

How did Hildegard perceive her role in the polemical texts that she had written? What concept lies at the core of these texts? Answering these questions would help us better place Hildegard's polemical activity, when comparing it to that of other famous contemporary authors of anti-heretical texts. Hildegard does not directly address the problem of heresy, which can intrinsically be a convincing argument that the heretics were not her audience. In more than a few aspects, Hildegard resembles Bernard of Clairvaux (1090-1153), who also approached the problem of heresy over the course of several sermons on the Song of Songs. But compared to Bernard, who used to preach in his own name and could therefore present his own approach when dealing with heresy, ${ }^{37}$ Hildegard was careful to attribute the utterance to God's Grace made manifest.

32 On the enclosure regime in the twelfth century, see Hotchin, Enclosure and Containment, cf. Felten, What Do We Know About the Life of Jutta. There are two major sources that elaborate on the necessity of a strict enclosure for women, dating from around the middle of the twelfth century: Speculum virginum and Aelred of Rievaulx's treaty De institutione inclusarum.

33 Zerfaß, Streit um die Laienpredigt; Bynum, Docere Verbo et Exemplo.

34 Kienzle, The Prostitute-Preacher.

35 Bernard of Fontcaude, Liber adversus Waldensium sectam in PL 204, 827B-828A: Nec dicitur hic, quia praedicavit vel docuit; sed »locuta est de Christo omnibus, qui exspectabant redemptionem Israel. «Non est idem, praedicare et loqui. [...] Cum igitur aliud sit donum prophetiae, aliud sermo doctrinae, secure concesserim, Annam, seu quasdam mulieres prophetasse; nec tamen consequenter dicendum erit, easdem docuisse; alioqui male posuit Apostolus eadem quasi diversa.

36 Cf. Blamires, Women and Preaching, 150.

37 For a detailed analysis of Bernard of Clairvaux's anti-heretical preaching, see Kienzle, Cistercians, Heresy, and Crusade, 78-108. 


\section{Hildegard's Concept of Teaching}

Franz Felten offered a brief but concise description of Hildegard's public persona as that of a "conservative reformist « $^{38}$, which would also best describe the prophetical authority ascribed to her. ${ }^{39}$ These two concepts are essential for understanding how Hildegard's authority functioned as both a prophetess and a reformist. Her texts not only plead for, but also impose and reinforce the necessity of reform, while preserving a perspective of society rooted in the Benedictine tradition. Hildegard, raised as an oblate, ${ }^{40}$ would have been part of this milieu from an early age. This aspect becomes visible when we look closer at both her concept of teaching and her understanding of the role which she envisaged for herself in the process of teaching publicly. Her first visionary work, Sciuias, discusses at length several aspects of teaching in the second book, through the inclusion of three visions that deal with the order of the Church, the sacraments and the Devil's actions against them.$^{41}$ Over the course of these visions, good teaching appears as a means for both the edification and articulation of the female figure of the Ecclesia. Furthermore, it constitutes the attribute of priests who are scarrying the health-giving chrism and announcing the divine law to the people. $\mathbf{~}^{42}$

When talking about omnis ecclesiasticus ordo ${ }^{43}$, the order comprised of all bishops and priests, she discusses teaching in relation to chastity and correct ordination, two themes of major interest for the movement of church reformation. Her definition, which is obviously rooted in the ecclesiastical tradition, alludes clearly to a pastoral understanding which emphasises the model of docere verbo et exemplo by giving similar importance to the act of preaching and to physical and spiritual perfection. Although teaching is defined by Hildegard in a very general manner, without going into the details about what it should contain, she nonetheless points towards the major aspects that need to be taken into consideration by a proper teacher: good intentions (rectam intentionem), work of activity (perfectum opus operationis) and wholeness of chastity (castitas integritatis). What is more, through penitence, the clergy's missteps from the role that the divine office offered to them, namely that of preaching through word and deed (verbo et exemplo), can be corrected..$^{44}$ Basically, the idea at stake here is that priests, through their office, ought to address a broader audience in a performative manner, in other words by offering a living example of their teaching.

38 Felten, Noui esse uolunt.

39 On the process of Hildegard's authorization, see Van Engen, Letters and the Public Persona; Van Engen, Authorship, Authority, and Authorization. Another type of analysis of the concept of authority, deeply influenced by a Pseudo-Dionysian tradition, can be found in Meier, Autorschaft im 12. Jahrhundert.

40 On the practice of oblation, see de Jong, In Samuel's Image. Hildegard's oblation and education are discussed in Flanagan, Hildegard of Bingen, 22-31.

41 Hildegard of Bingen, Scivias II. 5-7, eds. Führkötter and Carlevaris, 172-325.

42 Hildegard of Bingen, Scivias II. 5, eds. Führkötter and Carlevaris, 177: [...] ipsorum saluberrima pigmenta gestantes fideliter plateas et uillas et ciuitates atque alia loca regionum et terrarum pertranseunt, et populo diuinam legem annuntiant. English translation in Hildegard of Bingen, Scivias, trans. Hart and Bishop, 203.

43 Hildegard of Bingen, Scivias II. 4, eds. Führkötter and Carlevaris, 166-167.

44 Hildegard of Bingen, Scivias II. 5, eds. Führkötter and Carlevaris, 178-179. 
How does Hildegard see her own mission fit within this quite rigid model of orthodoxy? Like many major visionary works, some of her writings reinstate the motif of a world turned upside down, ${ }^{45}$ in which, against the backdrop of a lack of zeal from the ecclesiastical office holders, the divinely established order is threatened by the devil. ${ }^{46}$

A letter requested by the provost of the cathedral of St. Peter in Trier, which Hildegard had visited in order to warn and advise the local office holders in the Trier diocese, offers a hint of how she actually understood the prophetical call as underpinning, and thus legitimizing, her reformist activity. It is not surprising that Hildegard addressed such an essential discussion on the prophet's role within society to one of her most important audiences, comprised of both ecclesiastic and monastic figures, as her direct links to Trier are supported by genealogical evidence (since Andrew, one of Hildegard's nephews, served as Archbishop of Trier) as well by the manuscript transmission - both these connections are fairly well reflected in her Epistolarium and in the Vita.

In her response, Hildegard denounces the apathy of the masters and superiors of the Church towards their pastoral duties and then engages in a long rendition of Church History, in a manner that is typical for the works oriented towards the history of salvation. Amongst other aspects, she touches upon the role reserved for prophets in this global outlook:

For He established the prophets first to be the head, the wise to be the eyes, the teachers to be the mouth, just as all things came into being by the Word of God. And, then, because the rest of the body, that is, the faithful, will do good works, as I have said, God will place their head in His lap, that is to say, He will reveal the meaning of prophecy to them. ${ }^{47}$

We are here presented with a threefold division: prophets, wise ones, and teachers. One can catch a glimpse of how this scheme of disseminating divine knowledge was meant to function by looking at the correspondence of the magistra with her last collaborator, Guibert of Gembloux (1124-1213). In a second letter written to Hildegard, he presents the reader with outstanding details about the way in which her teaching might have functioned in the public space par excellence - the Church. After receiving Hildegard's letter of reply, Guibert underwent a solitary reading, of a private and mystical sort, having previously gone through a ritual of self-cleansing through prayer. He then started translating it into the vernacular, in order to read it publicly in the Church to a mixed audience the following day and even to offer a copy of the letter to all those who were present at that time. ${ }^{48}$

45 This is quite a classical theme in the rhetoric of Gregorian Reform. For a broader contextualization, see Bynum, Docere Verbo et Exemplo, 22-58.

46 A theme which is discussed at length in Hildegard of Bingen, Scivias II. 7, eds. Führkötter and Carlevaris, 273-325.

47 Hildegard of Bingen, Epistula 223R, ed. van Acker, 494-495: Ipse namque prophetas primum constituit uelut caput, sapientes uelut oculos, doctores uelut os, sicut etiam per uerbum Dei omnia facta sunt. Et quia deinde reliqua membra, scilicet fideles, bona operabuntur, ut dictum est, Deus in sinum eorum caput ponet, id est intellectui ipsorum prophetiam aperiet. Translated in Hildegard of Bingen, Letter 223R, ed. Baird and Ehrman, 21.

48 Guibert of Gembloux, Epistula 18, ed. Derolez, 225-234. 
Hildegard, assuming a prophetic identity which made her a vessel of revealed teaching, did not attempt to substitute herself for the de facto teachers, whose association with the Ecclesia's mouth is not fortuitous, and to whom speaking is attributed, in other words, the duty of teaching the laity. They were to guide the faithful through mediated teaching and through their own example. On the other hand, however, direct access to revealed knowledge places prophets and consequently Hildegard in a vastly superior position to any other human instances. In other words, it offered her the role of judge and mediator, one who could write and admonish, but without public instruction in a public space, therefore without the right to preach. As such, her understanding of the concept of teaching must be traced back to the vocabulary that is specific to Benedictine culture, which alludes to religious teaching and pastoral activity.$^{49}$ It thus becomes clear how religious women, carefully understanding and observing the boundaries of their cultural environment, could assume the social role of informal instructors outside their communities, achieving this without being perceived as undermining the acceptable confines of orthodoxy.

As has already been discussed in the opening section, Alan of Lille distinguished three types of teaching, namely preaching (or praedicatio), doctrina, and prophetia. According to him, only preaching - which is opened to a broader audience - is clearly linked with the idea of "public", as doctrina and prophetia seem to lack this dimension. If we cumulate this statement with Hildegard's scheme, described above, it becomes clear that preaching was an activity which could only have been performed by those who were designated through a formal office to perform it and who were instructed by the upper layer of spiritual experts in order to instruct those placed on a lower spiritual stratum - a scheme which strongly resembles the pseudo-Dionysian ideal of transmitting the idea of God. For Hildegard's particular case, as later for that of Bernard of Fontcaude, this seems important as most sources written by or about her are built on the image of the unlearned feminine figure..$^{50}$ Yet, when she presents herself as a prophetess, she acts as a disseminator of divine knowledge.

\section{On False Teaching}

Focusing now on "false teaching " offers a good vantage point in distinguishing between various stages of the anti-heretical discourse in Hildegard's writings. Having established that she perceived her position as guardian of "good teaching ", Hildegard seems to implicitly assume the role of informal teacher of the clerics, or, following a pattern frequently used in the world of schools to designate the masters of equally great disciples, ${ }^{51}$ to shape herself as a magistra magistrorum. From this position, she deals with the problem of false teaching. As an instructor with direct access to divine knowledge or Truth, it was Hildegard's mission to admonish the teachers of the many. Although exhortation was to be performed only within the framework of officium caritatis, that is, in the name of true Christian charity, its main function was

49 Ferzoco and Muessig, Medieval Monastic Education; Steckel, Kulturen des Lehrens, 116-124.

50 Meier, Eriugena im Nonnenkloster.

51 For an analysis of the relationship between master and students, as reflected in the vocabulary that is employed, see Steckel, Doctor Doctorum. 
to correct error. While some errors could be corrected by penance, others proved to be not only persistent but also dangerous for the entire ecclesiastical edifice, precisely because they resisted correctio. Under these circumstances, the intention of correcting motivated the use of invective to denounce the wrongdoings in a forceful manner, thus enabling the polemical potential of the discourse.

Analyzing the historical circumstances under which Hildegard's first major book of visions was created (Sciuias - around 1141-1152), leaves no doubt why distinguishing between good and bad teaching lies at the core of Hildegard's activity. Heresy shook many parts of the Latin West and manifested itself in various forms; echoes of this complex spiritual phenomenon could not pass without leaving traces in Hildegard's early writings, as it offered a good legitimation for the informal office of teacher of teachers.

While one might trace an early allusion to heresy as far back as her letter to St. Bernard of Clairvaux, ${ }^{52}$ a longer meditation on this subject can be found in Sciuias, where it is included in the broader discussion about the devil's work in society. ${ }^{33}$ She starts by addressing the heretics sharply as uiscera eiusdem incongruentis bestie (गthe very bowels of that unnatural beast`). ${ }^{54}$ Then, assuming God's voice, she continues as follows:

You, you evil deceivers, who labour to subvert the Catholic faith. You are wavering and soft, and thus cannot avoid the poisonous arrows of human corruption, which you employ as you wish against the Law. And after you pour out your lust in the poisonous seed of fornication, you pretend to pray and falsely assume an air of sanctity, which is more unworthy in My eyes than the stinky mire. [...] you are worse than earlier people, because you perceive the true law of God but stubbornly abandon it. ${ }^{55}$

The work that contained this vision was being completed during a period when several heretical groups were assumed to be active in various dioceses of the Rhinelands. It is therefore no surprise that the Hildegardian anti-heretical meditation presents countless similarities in language to other texts which dealt with this problem directly. One key source in this regard is provided by the Premonstratensian prior Evervin of Steinfeld (d.1152), who sent a letter to Saint Bernard in 1143, urging him to tackle the problem of heresy once more, ${ }^{56}$ as old and new threats were menacing the diocese of Cologne. While the old heretics are, as Malcom Lambert has suggested, presented as rigorists or promoters of a radical form of ascetic life who would

52 See the letter sent to Bernard of Clairvaux, around 1147, in which she alludes to multa schismata sunt in hominibus (there are many schisms among people - my translation) cf. Hildegard of Bingen, Epistula 1, ed. van Acker, 4.

53 Hildegard of Bingen, Scivias II. 7, eds. Führkötter and Carlevaris, 307-325.

54 Hildegard of Bingen, Epistula 169R, ed. van Acker, 381.

55 Hildegard of Bingen, Scivias II. 7, eds. Führkötter and Carlevaris, 322: [...] uos pessimi deceptores estis qui fidem catholicam subuertere laboratis. Vos instabiles et molles ad deuitandum uenenosas sagittas humanae pollutionis estis, quas secundum uoluntatem uestram contra legem exercetis. Vnde postquam uenenoso semine fornicationis libidinem uestram euacuatis, tunc ficte oratis et sanctitatem uobis fallaciter imponitis, quod oculis meis foetente luto indignius est. [...] peiores priori populo exsistentes, quoniam ueram legem Dei cernentes, eam pertinaciter abicitis.

56 See Bernard's sermon against Henry the Monk in Wakefield and Evans, Heresies of the High Middle Ages, $122-124$. 
refuse to obey the ordained clerics on the grounds of their impurity, ${ }^{57}$ the new ones (>certain other heretics in our land differing completely «) carry a number of resemblances to the Cathars (although Evervin does not label them as such). ${ }^{58}$ Beyond the perfunctory description of the various types of heretics, Evervin's letter provides three important elements. First and foremost, the Premonstratensian prior associates all of them with the heretics that sshall appear toward the end of the world ${ }^{59}$ secondly, their audience is extremely large and encompasses both lay as well as spiritual people, and thirdly, they are accompanied by women despite pretending to be chaste. ${ }^{60}$ In the sermon that Saint Bernard apparently wrote at the suggestion of Evervin as a part of the commentary on the Song of Songs, ${ }^{61}$ the former insisted at length on the point concerning the scandalous association of women to these heretical groups. ${ }^{62}$

By quickly reviewing the three sources, it becomes clear that Hildegard makes use of all major categories of anti-heretical preaching topoi, namely that of demonization, pollution, threat to social order, and apocalypticism, in a similar manner to her two contemporaries. ${ }^{63}$ What is more, in what could be considered the first stage of her anti-heretical discourse, Hildegard seems to be faithful to the standard imprecatory discourse, employed with much skill and with impressive imagination.

\section{Hildegard as a Polemicist}

While Sciuias cannot be specifically linked to a certain heretical movement, later in her life Hildegard appears to have been actively involved in a campaign directed against the snew heretics s that Evervin of Steinfeld's letter references, namely those who have been subsequently labelled Cathars. ${ }^{64}$ The one who used the term for the first time to name this heretical group, targeting it in one of his treatises, is Eckbert of Schönau (d. 1184). Active in his youth as a canon in Bonn, he disputed with Cathars from Bonn, Cologne, and later from Mainz. ${ }^{65}$ This direct experience would have lain at the basis of his most famous Sermons against the

57 Lambert, Medieval Heresy, 64. For the English translation of the letter see Wakefield and Evans, Heresies of the High Middle Ages, 127-132. Evervin calls them rapostolics of Satan<, mocking their apostolic aspiration and the label of sElectr.

58 Wakefield and Evans, Heresies of the High Middle Ages, 130.

59 Namely those announcing the coming of the Antichrist: ras though already their prince was about to be loosed and the day of the Lord were at hand in Wakefield and Evans, Heresies of the High Middle Ages, 128, cf. II Thessalonians 2.9-2.10.

60 Wakefield and Evans, Heresies of the High Middle Ages, 132: »These apostolics of Satan have among them women vowed to continence (so they say): widows, virgins, and their wives, some among the Elect, some among the believers."

61 Kienzle, Tending the Lord's Vineyard; Kienzle, Cistercians, Heresy, and Crusade, 78-108.

62 Bernard of Clairvaux, Sermo 65, eds. Leclercq et al. 175: Alioquin temere tibi usurpas illorum dispensationem, quorum sanctitatem non habes. Cum femina semper esse, et non cognoscere feminam, nonne plus est quam mortuum suscitare? [...] Quotidie latus tuum ad latus juvenculae est in mensa; lectus tuus ad lectum eius in camera, oculi tui ad illius oculos in colloquio, manus tuae ad manus ipsius in opere; et continens vis putari?

63 This taxonomy is proposed and discussed in Kienzle, Preaching as Touchstone, 21.

64 Manselli, Ecberto di Schönau; Moore, War on Heresy, 167-173.

65 On Eckbert of Schönau's activity see, Brunn, Des contestataires aux « Cathares », 207-220. 
Cathars. Corroborating different accounts that refer to the period between 1143-1163, R. I. Moore notes that "the triangle between Liege, Cologne and Trier not only introduces us, in two sources, to the word Cathar, but provides for the first time a full and detailed account of those to whom it was applied. ${ }^{66}$ Decades ago, Raoul Manselli tried to integrate Hildegard's writing into a concerted action, led by Eckbert of Schönau, against the Cathars. ${ }^{67}$ Indeed his sister, Elisabeth, following the divine command, took up the pen to write against the Cathars. She also tried to convince her older visionary fellow and mentor to join the fight. ${ }^{68}$ However, Hildegard gave no formal answer to Elisabeth's letter of petition that was passed down to us. ${ }^{69}$

It is in this context that Hildegard produced a series of visions, sometimes labelled sermons by scholars, in which she reveals a more innovative polemical discourse, engaging with the theme of false teaching. ${ }^{70}$ At least two of her letters attest her approach to this central polemical aspect of her work. One was written at the request of a monastic community, probably from Mainz. ${ }^{71}$ The second addresses the clergy in Cologne. According to the letter pairing in her Epistolarium, the former letter comprised an older work, as the monks showed interest in Hildegard's anti-Cathar writings. ${ }^{72}$ The latter of the two is her most popular and probably best-known work. It was produced at the request of Dean Philip of Cologne. From his letter of petitio, we infer that this text is based on a previous spoken communication, of which we know too little to label it more specifically. ${ }^{73}$ It is worth noting that Philip does not offer a single reference or clue to the existence of Cathars or of any other heretical sect.

What does a closer look at this second phase of Hildegard's polemical activity reveal? Intriguingly enough, Hildegard precisely dates the treatise sent to the presumed monastic community in Mainz - July $1163 .{ }^{74}$ This predates the trial against the Cathars in Cologne by one month; the heretics, namely four men and a young woman according to the chronicles of the city, were defeated in a debate, and later burnt at the stake..$^{75}$ Although this writing briefly mentions the problem of ineffective clerical teaching, Hildegard insists on the poisonous

66 Moore, Origins of European Dissent, 175-176.

67 Manselli, Amicizia spirituale.

68 Elisabeth of Schönau, Liber visionum III, ed. Roth, 70-75.

69 It is quite intriguing, however, that the "MSS of Redaction D of Elisabeth's visionary collection « also contains a small treatise written by Hildegard and directed against the Cathars; Clark, Elisabeth of Schönau, 157, n. 73.

70 It is fairly problematic to judge to what degree the echoes of this new heretical outbreak could have either appeared in her writings many years later, or actually inspired other works which did not directly deal with the problem. See Kienzle's interpretations versus those of Brunn.

71 Hildegard of Bingen, Epistula 169R, ed. van Acker, 378-382.

72 Hildegard of Bingen, Epistula 15R, ed. van Acker, 34-47.

73 Hildegard of Bingen, Epistula 15, ed. van Acker, 33: Rogamus etiam, ut ea que uiua uoce nobis prius dixistis, litteris quoque commendetis et nobis transmittatis, quia, dum carnalibus concupiscentiis dediti sumus, spiritalia, que nec frequenter uidemus nec audimus, facile per negligentiam obliuioni tradimus.

74 Hildegard of Bingen, Epistula 169R, ed. van Acker, 378: Mense Iulio presentis anni, qui est millesimus centesimus sexagesimus tertius dominice incarnationis, aspiciens a longe uidi in umbra uere uisionis sub altare quod est ante oculos Dei, et etiam uidi sub thronum Dei.

75 Chronica regia Coloniensis in MGH SRG 18, ed. Waitz, $114 \mathrm{cf}$. with the account offered by Dietrich of Deutz in MGH SS 13, ed. Waitz, 286-287. 
teaching of the heretics, though in a somewhat general and ambiguous manner. While some of her contemporaries already labelled them as Cathars or at least as heretics, she does not use these or any similar terms, instead naming her opponents by using older topoi such as sadduceis similes (like the Sadducees), similes illis qui Baal Deum nominant (similar to those who call Baal God), sulphurei montes (sulphurous mountains), similes scorpionibus (like scorpions), and peiores Iudeis (worse than the Jews). ${ }^{76}$ However, she seems to hint towards the central theological aspect in relation to which the Cathars are deviating from the orthodox line, as she alludes to the idea of a false teaching which denies God as first principle. ${ }^{77}$ Some of the invectives used previously in Sciuias are reprised here and a few new ones are added, especially the accusation of false prophecy:

And just as the prophets preceded the Lord and prophesied in the way of salvation, demonstrating that He was filled with all the virtues of justice, so too do these precede the beast, embracing the filth and wickedness of all evils, going the way of the errant. For these prophets were inspired and taught by the finger of God, just as the devil fills these people with blasphemy, wickedness, and the falseness of all evil. ${ }^{78}$

Going back to the letter addressed to the clergy of Cologne, Hildegard employs arguments of a somewhat different nature. She develops the idea that priests who do not preach against heresy cannot be called actual teachers. The treatise begins by clearly differentiating between the priests who are good teachers and the deviant ones that stray from the precepts of good teaching. This time, her admonitory voice is full of wrath and she does not hesitate to gradually stress all the sins and the faults that the deviant priests are guilty of. The text culminates with them being denounced as impeding the act of teaching on which the entire edifice of Ecclesia rests, by opposing their pastoral vocation: syou do not properly teach your subordinates, nor indeed do you even allow them to seek instruction from you. ${ }^{79}$ She reiterates, time and time again, that most of the priests had ceased to represent a moral compass for the believers, contributing to the increasing popularity of false teachers.

While the identity of these false teachers is never disclosed, Hildegard extensively decries their falsely pious behaviour which helps them gain popularity amongst maioribus secularibus principibus ('great secular princes`) ${ }^{80}$ and women. If we compare the language used in this second letter to that in Sciuias, which seems to have been influenced by Bernard, the charges of sexual promiscuity of the heretics are missing from the text of this sermon. ${ }^{81}$

76 Hildegard of Bingen, Epistula 169R, ed. van Acker, 380-381.

77 Hildegard of Bingen, Epistula 169R, ed. van Acker, 381: Hi sunt qui prima principia negant, scilicet quod Deus omnia creauit et ea germinando et crescendo procedere iussit.

78 Hildegard of Bingen, Epistula 169R, ed. van Acker, 381: Et sunt etiam uiscera eiusdem incongruentis bestie que excipit et exspuit pessimam immunditiam, et precedunt eam, amplectendo spurcitiam ac nequitiam omnium malorum, per uiam errantium, sicut prophete Dominum prophetauerunt in uia salutis, eum ostendentes cum omnibus uirtutibus iustitie; quos digitus Dei inspirauit et docuit, sicut et diabolus blasphemia et nequitia et mendacio omnium malorum istos imbuendo replet.

79 Hildegard of Bingen, Epistula 15R, ed. van Acker, 37: subditos uestros non imbuitis, nec eos doctrinam a uobis querere permittitis.

80 Hildegard of Bingen, Epistula 15R, ed. van Acker, 40.

81 Hildegard of Bingen, Epistula 15R, ed. van Acker, 41-42: Ipsi autem in inceptione seductionis erroris sui mulieribus dicent: Non licet uos nobiscum esse, sed quoniam rectos doctores non habetis, nobis obedite et quecumque uobis dicimus et precipimus, facite et salue eritis. 
Furthermore, the image of chastity seems to gain a new understanding, with magical undertones: the devil has given the evildoers perfect chastity and they are now able to resist temptation..$^{82}$ The stress upon the physical perfection of the heretics, inspired by the devil, is meant to highlight the flaws of the clerical teachers even more. It becomes clearer that correct teaching is at stake now, as the seducers of the layman could oppose the corrupt clergy precisely through their physical purity, which should have been an external sign of a good priest. The reference to the persecution of righteous teachers, unleashed by the heretics, makes more sense when considering that this logic of thought seems to be behind it. The very head and stability of the Church are directly menaced by these persecutors. ${ }^{83}$

\section{Conclusions}

It is safe to conclude that Hildegard's polemical activity shows a profound influence and similarity to that of other monastic authors of her time. Nonetheless, in her case, the entire discussion revolves around the notion of prophet or prophetess - understood as the highest magister or magistra in Christian society - upon whom the responsibility of safeguarding and restoring divine doctrine falls. Hildegard repeatedly stresses that prophets should restore the good teaching by admonishing those who fail to teach, as this is an integral part of the duty for which they were ordained. This can be traced even in her famous letter addressed to the pastors of the church, in a passage that contains her meditation on the function attributed by the divine knowledge to each of the three major magisterii of the Church. ${ }^{84}$ Moreover, given her position, it is quite interesting how most texts referring to Hildegard's activity neither use predicare nor give a clear picture of Hildegard speaking publicly, meaning in front of a broader audience comprised of laypeople. Thanks to her last collaborator, Guibert of Gembloux, we have a testimony of an instance in which her visions were publicly read, although not by Hildegard herself. Despite being placed on an elevated plane owing to her prophetic knowledge, her discourse remains confined to the strict frames of the orthodox line of the twelfth century, which did not look favourably upon women preachers.

The texts discussed previously clearly illustrate that the concept of teaching is a tool, which Hildegard handled with care and skill. The implicit question is who were her targets? At a first glance, the obvious answer to this question would seem to be that the heretics are the intended receivers of Hildegard's invectio, especially when the idea of false teaching is employed. Yet, upon a closer inspection, it becomes clear that the reason why Hildegard did not directly address heretics is that her intended audience was meant to be restricted to those clerics and monks who were duty-bound to teach through word and example. Thus, aimed

82 Hildegard of Bingen, Epistula 15R, ed. van Acker, 40-41: Nam diabolus per aerios spiritus hec operatur, qui propter praua opera hominum in sufflatu uenti et aeris ita innumerabiles circa quosdam discurrunt sicut musce et culices, qui in ardore caloris homines pre multitudine sua infestant. Ipse enim homines istos hoc modo infundit, quod castitatem eis non aufert et quod eos castos esse permittit, cum castitatem habere uoluerint; unde mulieres non amant, sed eas fugiunt.

83 Hildegard of Bingen, Epistula 15R, ed. van Acker, 41: Nam alii homines qui eo tempore in fide catholica errant, istos timebunt et seruili seruitio eis ministrabunt, et quantum poterunt eos imitabuntur. Cumque isti cursum erroris sui hoc modo compleuerint, doctores et sapientes, qui tunc in catholica fide persistunt, undique persequentes expellent, sed tamen non omnes, quoniam aliqui illorum fortissimi milites in iustitia Dei sunt.

84 See the passage from Hildegard's letter addressed to the clergy of Trier quoted above, Epistula 223R. 
at the bad and unchaste clergymen who were blamed for the success of false teachers, her harsh admonitory tone echoes the prophetical increpatio. ${ }^{85}$ This vision was quite likely meant to be performed as a sermon in front of a broader audience by a good priest, thus drawing a clear line between the good and the bad clergy. One can easily imagine that a public reading by Philip of such an extreme form of admonition might have contributed to the release of its full offensive potential, transforming it into an invectio. This scenario becomes even more plausible when placed in the context of the Schism within the Latin Church. ${ }^{86}$

Although Hildegard has never been acknowledged as a magistra magistrorum in the same way in which Bruno the Carthusian (1030-1101), for instance, was recognized by his pupils, the visionary nun of Bingen nonetheless played this role informally for many of her correspondents, as a more careful analysis of her letter collection plainly reveals. Through prophetical admonition, Hildegard was always careful to present herself as a guardian and informal disseminator of sacred teaching, despite her womanly condition. From this elevated plane of the prophetical voice, she could produce an extremely powerful written discourse. Her writings do not offer many innovations in terms of reform or anti-heretical topoi. What they do offer is her rather unique and allusive manner of adapting them. This style envelops her entire discourse, which is always carefully placed within the established boundaries of orthodoxy. This skilful polemical discourse proved to be appealing not only to her contemporaries, but also to future generations of polemicists. Its high degree of ambiguity, combined with the powerful invective, made it easy for it to be removed from its original context and adapted to suit other contexts - as would happen starting with 1230, when Gebeno of Eberbach (fl. 1220) wrote his Speculum futurorum temporum as a "Hildegardian breviary ${ }^{87}{ }^{87}$

\section{Acknowledgements}

The present study was supported by the Volkswagen Foundation within the framework of the Dilthey Fellowship led by Sita Steckel entitled »Diversitas religionum. Thirteenth-century foundations of European discourses of religious diversity". It is an extended version of a paper presented at the International Medieval Congress in Leeds 2016. The author is indebted to Sita Steckel and Julie Hotchin for reading and offering insightful comments on earlier drafts of this article.

85 On various stages of admonition, see de Jong, Admonitio and Criticism, 320-323.

86 Brunn, Des contestataires aux « Cathares », 247-262, cf. Moore, War on Heresy, 165-171.

87 Kerby-Fulton, Reformist Apocalypticism, 28-56. 


\section{References}

Aelred of Rivaulx, De Institutione Inclusarum: ed. Charles Hugh Talbot CCCM 1 (Turnhout, 1971).

Alan of Lille, Summa de arte praedicatoria, PL 210, col. 0109-0198A.

Bernard of Clairvaux, S. Bernardi Opera Vol. II. Sermones super cantica canticorum 36-86, eds. Jean Leclercq, Charles Hugh Talbot and Henri M. Rochais (Rome, 1958).

Bernard of Fontcaude, Liber adversus Waldensium sectam, PL 204, col. 0793-0840D.

Biller, Peter, Goodbye to Catharism?, in: Antonio C. Sennis (ed.), Cathars in Question (York, 2016) 274-312.

Blamires, Alcuin, Women and Preaching in Medieval Orthodoxy, Heresy, and Saints' Lives, Viator 26 (1995) 135-152.

Brunn, Uwe, Des contestataires aux " Cathares »: discours de réforme et propagande antihérétique dans les pays du Rhin et de la Meuse avant l'Inquisition (Paris, 2006).

Bynum, Caroline Walker, Docere Verbo et Exemplo: An Aspect of Twelfth-Century Spirituality (Missoula, Montana, 1979).

Chronica Regia Coloniensis, ed. Georg Waitz, MGH SRG 18 (Hannover, 1880).

Clark, Anne L., Elisabeth of Schönau: A Twelfth-Century Visionary (Philadelphia, 1992).

Connell, Charles W., Popular Opinion in the Middle Ages: Channeling Public Ideas and Attitudes (Berlin, 2016).

Davies, Wendy, and Paul Fouracre (eds.), The Settlement of Disputes in Early Medieval Europe (Cambridge, 1992).

Elisabeth of Schönau, Die Visionen der Hl. Elisabeth und die Schriften der Aebte Ekbert und Emecho von Schönau. Ein Beitrag zur Mystik und Kirchengeschichte. Nach den OriginalHandschriften. Mit historischem Abrisse des Lebens der Hl. Elisabeth, der Aebte Ekbert und Emecho von Schönau, ed. Ferdinand W. E. Roth (Brünn, 1884).

Embach, Michael, Die Schriften Hildegards von Bingen: Studien Zu Ihrer Überlieferung Und Rezeption Im Mittelalter Und in Der Frühen Neuzeit. Erudiri Sapientia 4 (Berlin, 2003).

Engen, John H. Van, Rupert of Deutz (Berkley,1983).

Engen, John Van, Letters and the Public Persona of Hildegard of Bingen, in: Alfred Haverkamp (ed.), Hildegard von Bingen in ihrem historischen Umfeld. Internationaler wissenschaftlicher Kongreß zum 90o-jährigen Jubiläum 13-19. Sept. 1998 in Bingen (Mainz, 2000) 375-418.

Engen, John Van, Authorship, Authority, and Authorization: The Cases of Abbot Bernard of Clairvaux and Abbess Hildegard of Bingen, in: Shari Boodts, Johan Leemans, and Brigitte Meijins (eds.), Shaping Authority: How Did a Person Become an Authority in Antiquity, the Middle Ages and the Renaissance? (Turnhout, 2016) 325-362.

Felten, Franz J., Noui esse uolunt ... deserentes bene contritam uiam ... Hildegard von Bingen und Reformbewegungen im religiösen Leben ihrer Zeit, in: Rainer Berndt (ed.), `Im Angesicht Gottes suche der Mensch sich selbstr: Hildegard von Bingen (1098-1179) (Berlin, 2001) 27-86.

Felten, Franz J., Hildegard von Bingen 1198-1998 - oder: Was bringen Jubiläen für die Wissenschaft?, Deutsches Archiv für Erforschung des Mittelalters 59/1 (2003) 165-194.

Felten, Franz J., What Do We Know About the Life of Jutta and Hildegard at Disibodenberg and Rupertsberg?, in: Beverly Mayne Kienzle, Debra L. Stoudt and George Ferzoco (eds.), A Companion to Hildegard of Bingen. Translated from German by John Zaleski (Boston, 2014) 15-38. 
Ferzoco, George and Muessig, Carolyn (eds.), Medieval Monastic Education (London, 2000). Flanagan, Sabina, Hildegard of Bingen, 1098-1179: A Visionary Life (London, 1989).

Grellard, Christophe and Frédérique, Lachaud (eds.), A Companion to John of Salisbury (Leiden, 2014).

Griffiths, Fiona J., 'Like the Sister of Aaron<. Medieval Religious Women as Makers and Donors of Liturgical Textiles, in: Gert Melville and Anne Müller (eds.), Female »Vita Religiosa" between Late Antiquity and the High Middle Ages: Structures, Developments and Spatial Contexts, Vita Regularis 47 (Zürich, 2011).

Guibert of Gembloux, Epistolae Gviberti Gemblacensis Epistolae quae in codice B. R. Brux. 55275534 inueniuntur. Pars I Epistolae I-XXIV, ed. Albert Derolez, CCCM 66 (Tvrnholti, 1988).

Hettema, Theo L. and Kooij, Arie van der (eds.), Religious Polemics in Context: Papers Presented to the Second International Conference of the Leiden Institute for the Study of Religions (Lisor) Held at Leiden, 27-28 April, 2000 (Assen, 2004).

Hildegard of Bingen, Scivias, ed. Adelgundis Führkötter and Angela Carlevaris, CCCM 43-43A (Tvrnholti, 1978).

Hildegard of Bingen, Scivias, trans. Columba Hart and Jane Bishop (New York, 1990).

Hildegard of Bingen, Epistolarivm, Pars prima, I-XC, ed. Lieven van Acker, CCCM 91 (Turnhout, 1991).

Hildegard of Bingen, Epistolarivm. Pars secvunda, XCI-CCLr, ed. Lieven van Acker, CCCM 91A (Turnhout, 1993).

Hildegard of Bingen, The Letters of Hildegard of Bingen, Vol. 1, trans. Joseph L. Baird and Radd K. Ehrman (New York, 1994).

Hildegard of Bingen, The Letters of Hildegard of Bingen, Vol. 2, trans. Joseph L. Baird and Radd K. Ehrman (New York, 1998).

Hildegard of Bingen, Epistolarivm. Pars tertia CCLI-CCCXC, eds. Lieven Van Acker and Monika Klaes-Hachmöller, CCCM 91B (Turnhout, 2001).

Hildegard of Bingen, The Letters of Hildegard of Bingen, Vol. 3, trans. Joseph L. Baird and Radd K. Ehrman (New York, 2004).

Hildegard of Bingen, Hildegard of Bingen's Unknown Language, ed. and trans. Sarah Lynn Higley (New York, 2007).

Holbach, Rudolf, Hildegard von Bingen und die kirchlichen Metropolen Mainz, Köln und Trier, in: Alfred Haverkamp (ed.), Hildegard von Bingen in ihrem historischen Umfeld. Internationaler wissenschaftlicher Kongreß zum 9oojährigen Jubiläum, 13-19 September 1998, Bingen am Rhein (Mainz, 2000) 71-115.

Hotchin, Julie, Enclosure and Containment: Jutta and Hildegard at the Abbey of St. Disibod, Magistra: A Journal of Women Spirituality in History 2/2 (1996) 103-123.

Hotchin, Julie, Female Religious Life and the Cura Monialium in Hirsau Monasticism, 1080 to 1150, in: Constant Mews (ed.), Listen Daughter! The Speculum Virginum and the Formation of Religious Women in the Middle Ages (New York, 2001) 59-83.

Iogna-Prat, Dominique, Order and Exclusion: Cluny and Christendom Face Heresy, Judaism, and Islam (1000-1150) (Ithaca, 2002).

John of Salisbury, The Letters of John of Salisbury 2: The Later Letters (1163-1180), ed. William J. Millor and Christopher N. L. Brooke, (Oxford, 1979).

Jong, Mayke de, In Samuel's Image: Child Oblation in the Early Medieval West (Leiden, 1996). 
Jong, Mayke de, Admonitio and Criticism of the Ruler at the Court of Louis the Pious, in: François Bougard, Régine Le Jan and Rosamond McKitterick (eds.), La culture du haut Moyen Âge: une question d'élites? [Actes de la rencontre de Cambridge des 6, 7 et 8 septembre 2007] (Turnhout, 2009) 315-338.

Kerby-Fulton, Kathryn, Reformist Apocalypticism and Piers Plowman (Cambridge, 2007).

Kienzle, Beverly M., Tending the Lord's Vineyard: Cistercians, Rhetoric and Heresy, 11431229. Part I: Bernhard of Clairvaux, the 1143 Sermons and the 1145 Preaching Mission, Heresis 25 (1995) 29-61.

Kienzle, Beverly M., Defending the Lord's Vineyard: Hildegard of Bingen's Preaching against the Cathars, Medieval monastic preaching (Leiden, 1998) 163-181.

Kienzle, Beverly M., The Prostitute-Preacher. Patterns of Polemic against Medieval Waldensian Women Preachers, in: Beverly Mayne Kienzle and Pamela J. Walker (eds.), Women Preachers and Prophets through Two Millennia of Christianity (Berkeley, 1998) 99-113.

Kienzle, Beverly M., Preaching as Touchstone of Orthodoxy and Dissidence in the Middle Ages, Medieval Sermon Studies 43 (1999) 19-54.

Kienzle, Beverly M. (ed.), The Sermon (Turnhout, 2000).

Kienzle, Beverly M., Cistercians, Heresy, and Crusade in Occitania, 1145-1229: Preaching in the Lord's Vineyard (Rochester, New York, 2001).

Kienzle, Beverly M., Hildegard of Bingen and Her Gospel Homilies: Speaking New Mysteries (Turnhout, 2009).

Kienzle, Beverly M., Crisis and Charismatic Authority in Hildegard of Bingen's Preaching against the Cathars, in: Katherine L. Jansen and Miri Rubin (eds.), Charisma and Religious Authority: Jewish, Christian, and Muslim Preaching (Turnhout, 2010) 73-91.

Kienzle, Beverly M., Hildegard of Bingen and Public Voices of Women in Medieval Society, in: Rainer Berndt and Maura Zatonyi (eds.), Unversehrt und unverletzt. Hildegards von Bingen Menschenbild und Kirchenverständnis heute (Münster, 2015) 309-322.

Küsters, Urban, Formen und Modelle religiöser Frauengemeinschaften im Umkreis der Hirsauer Reform des 11. und 12. Jahrhunderts, in: Klaus Schreiner (ed.), Hirsau, St. Peter und Paul, 1091-1991. Geschichte, Lebens- und Verfassungsformen eines Reformklosters 2 (Stuttgart, 1991) 195-220.

Lambert, Malcolm D., Medieval Heresy: Popular Movements from the Gregorian Reform to the Reformation (Wiley, 2002).

Longère, Jean, La prédication médiévale (Paris, 1983).

Manselli, Raoul, Amicizia spirituale ed azione pastorale nella Germania del secolo XII: Ildegarde di Bingen, Elisabetta ed Ecberto di Schönau contro l'eresia catara, in: Raoul Manselli, Studi sulle eresie del secolo XII (second edition) (Roma, 1975) 211-220.

Manselli, Raoul, Ecberto di Schönau e l'eresia catara in Germania alla meta del secolo XII, in: Raoul Manselli, Studi sulle eresie del secolo XII (second edition) (Roma, 1975) 191-210.

Meier, Christel, Eriugena im Nonnenkloster? Überlegungen zum Verhältnis von Prophetentum und Werkgestalt in den figmenta prophetica Hildegards von Bingen, Frühmittelalterliche Studien 19 (1985) 466-497.

Meier, Christel, Autorschaft Im 12. Jahrhundert. Persönliche Identität Und Rollenkonstrukt, in: Peter von Moos (ed.), Unverwechselbarkeit. Persönliche Identität und Identifikation in der vormodernen Gesellschaft (Köln, 2004) 207-266.

Melve, Leidulf, Inventing the Public Sphere: The Public Debate During the Investiture Contest (c. 1030-1122). Brill's Studies in Intellectual History 154. (Leiden, 2007). 
Mews, Constant J., Male-Female Spiritual Partnership in the Twelfth Century: The Witness of Aberlard and Heloise, Volmar and Hildegard, in: Rainer Berndt and Maura Zatonyi (eds.), Unversehrt und unverletzt. Hildegards von Bingen Menschenbild und Kirchenverständnis heute (Münster, 2015) 167-183.

Mooney, Catherine. M., Authority and Inspiration in the Vitae and Sermons of Humility of Faenza, in: Carolyn Muessig (ed.), Medieval Monastic Preaching (Leiden, 1998) 123-144.

Moore, Robert I., The Origins of European Dissent (London, 1977).

Moore, Robert I., The War on Heresy: Faith and Power in Medieval Europe (Cambridge, Massachusetts, 2012).

Müller, Gerhard, Die hl. Hildegard im Kampf mit Häresien ihrer Zeit, in: Anton Philipp Brück (ed.), Hildegard von Bingen 1179-1979. Festschrift zum 800. Todestag der Heiligen (Trier, 1998) 171-188.

Muessig, Carolyn, What Is Medieval Monastic Preaching? An Introduction, in: Carolyn Muessig (ed.), Medieval Monastic Preaching (Leiden, 1998) 3-16.

Speculum virginum, ed. Jutta Seyfarth, CCCM 5 (Turnhout, 1990).

Steckel, Sita, Kulturen des Lehrens im Früh- und Hochmittelalter: Autorität, Wissenskonzepte und Netzwerke von Gelehrten (Köln, 2011).

Steckel, Sita, Doctor Doctorum: Changing Concepts of "Teaching" in the Mortuary Roll of Bruno the Carthusian ( $\dagger$ 1101), in: Hartmut Beyer, Gabriela Signori, and Sita Steckel (eds.), Bruno the Carthusian († 1101) and His Mortuary Roll. Studies, Text and Translations (Turnhout, 2014) 83-116.

Suchan, Monika, Mahnen und Regieren. Die Metapher des Hirten im früheren Mittelalter (Berlin, 2015).

Suerbaum, Almut, Southcombe, George and Thompson, Benjamin (eds.), Polemic: Language as Violence in Medieval and Early Modern Discourse (Farnham, Surrey, 2015).

Theodoric of Echternach, Vita Sanctae Hildegardis, ed. Monica Klaes, CCCM 127 (Turnhout, 1993) 19-71.

Wakefield, Walter Leggett and Evans, Austin Patterson (ed.), Heresies of the High Middle Ages: Selected Sources Translated and Annotated. Records of Western Civilization (New York, 1991).

William of Puylaurent, The Chronicle of William of Puylaurens: The Albigensian Crusade and Its Aftermath, edited by William. A. Sibly and Michael D. Sibly (Woodbridge, 2003).

Zerfaß, Rolf, Der Streit um die Laienpredigt: Eine pastoralgeschichtliche Untersuchung zum Verständnis des Predigtamtes und zu seiner Entwicklung im 12. u. 13. Jahrhundert (Freiburg im Breisgau, 1974). 